\title{
Afshin Ellian, Gelijn Molier en Bastiaan Rijpkema (red.), De strijd om de democratie. Essays over democratische zelfverdediging
}

\author{
Ronald Tinnevelt
}

Afshin Ellian, Gelijn Molier en Bastiaan Rijpkema (red.), De strijd om de democratie. Essays over democratische zelfuerdediging (Amsterdam: Boom, 2018), 416 p.

Het onlangs verschenen eindrapport van de staatscommissie parlementair stelsel (de commissie-Remkes) kent twee belangrijke thema's: 'het verbeteren van inhoudelijke representatie' en 'het versterken van de weerbaarheid van de democratische rechtsstaat'. ${ }^{1}$ Beide thema's hangen volgens de opstellers van het rapport nauw samen. Een verbeterde inhoudelijke representatie van onze parlementaire democratie - het verkleinen van de kloof tussen de inhoudelijke opvattingen van de Kamerleden en die van laagopgeleide kiezers - draagt bij aan de democratische gezindheid van burgers en versterkt daarmee de brede en maatschappelijke basis van de democratie. Deze maatschappelijke democratie vormt op haar beurt een van de beschermende lagen voor een goed functionerende en inclusieve democratie. De inhoudelijk verwante bundel De strijd om de democratie - onder redactie van de Leidse rechtsfilosofen Ellian, Molier en Rijpkema - deelt de achtergrondbekommernissen van het eindrapport maar zet vooral in op het tweede thema, de weerbaarheid van de democratie. Het belang van de democratische gezindheid (de 'liefde' voor de democratie en haar instituties) komt slechts zijdelings aan bod in bijdragen van onder andere Ellian, Van Schie en Cliteur.

Het uitgangspunt voor De strijd om de democratie is het conflict dat in 2017 tussen de Hongaarse minister-president Viktor Orbán en Eurocommissaris Frans Timmermans ontstond over de mogelijke sancties van de EU tegen Polen vanwege de voorstellen van de regeringspartij $\mathrm{PiS}$ om de positie van de rechterlijke macht te verzwakken. Dit specifieke uitgangspunt wordt gebruikt om drie algemene aspecten van het vraagstuk van democratische zelfverdediging naar voren te schuiven. Op de eerste plaats de bekende, maar daarmee niet minder belangrijke, vaststelling dat de ondergang van een democratie op democratische wijze bespoedigd kan worden (p. 9). Democratie en (democratische) rechtsstaat kunnen met elkaar op gespannen voet staan. Op de tweede plaats de vraag of de uitslag van een democratisch proces altijd gerespecteerd dient te worden of dat er goede redenen kunnen zijn om deze waar nodig terzijde te schuiven. Op de laatste plaats de rechtvaardiging die gegeven zou kunnen worden voor maatregelen - zowel op nationaal als op Europees niveau - die tot doel hebben om ondemocratische ontwikkelingen en partijen een halt toe te roepen.

1 Jaap Verschoor, red., Lage drempels, hoge dijken: democratie en rechtsstaat in balans. Eindrapport van de Staatscommissie Parlementair Stelsel (Amsterdam: Boom, 2018), 13. 
Met betrekking tot deze aspecten heeft De strijd om de democratie een dubbele ambitie. Op een algemeen niveau wil de bundel de 'politiek- en rechtsfilosofische bouwstenen' (p. 10) aandragen die nodig zijn voor een gedegen oordeel over de ontwikkelingen waarvan we getuigen zijn geweest in onder andere Polen en Hongarije. Op een meer specifiek niveau wil de bundel echter ook de filosofische onderbouwing geven voor het publieke en politieke debat dat de afgelopen jaren in Nederland is ontstaan 'over de grenzen van onze democratie en democratische zelfverdediging' (p. 10). Welke middelen hebben we om onze democratie te beschermen? Zijn deze toereikend? Welke andere maatregelen zijn politiek wenselijk en juridisch haalbaar? Deze politieke en juridische vragen leiden onvermijdelijk tot de politiek-filosofische vraag bij uitstek: 'wat is het wezen of de essentie van de democratie'? (p. 11) Het antwoord op deze vraag is immers bepalend voor de vraag of er een legitieme rechtvaardiging bestaat voor het tegengaan van ondemocratische en antidemocratische ontwikkelingen.

De strijd om de democratie bestaat uit drie delen: grondslagen, Europa en religie. Het eerste deel van de bundel is tevens het omvangrijkste deel. De rode draad vormt de eerdergenoemde vraag naar de essentie van de democratie of, om de titel van Hans Kelsens studie uit 1929 te gebruiken, de vraag naar het wezen en de waarde van de democratie. Het werk van diverse filosofische auteurs wordt gebruikt om deze vraag te beantwoorden en een theoretische onderbouwing te bieden voor de idee van weerbare democratie. Zo analyseert Gelijn Molier onder meer de theoretische rechtvaardiging die Gustav Radbruch in 'Der Mensch im Recht' en 'Gesetzliches Unrecht und übergesetzliches Recht' ontwikkelt, werkt Bart Verheijen Claude Leforts concept van onbepaaldheid uit en gebruikt Afshin Ellian Carl Schmitt, Hannah Arendt en Jacques Derrida om de dictatuur van de rechtsstaat te bespreken en de radicale openheid van de democratie te verdedigen. Een aantal van de bijdragen in het eerste deel gaan tevens de confrontatie aan met Bastiaan Rijpkema's notie van 'democratie als zelfcorrectie'. Rijpkema zelf werkt deze notie verder uit in het eerste hoofdstuk van de bundel en verdedigt deze tegenover eerdere kritieken. In het tweede deel van de bundel behandelen Leonard Besselink en Rick Lawson de vraag hoe de Europese Unie dient om te gaan met de afkalving van de democratische rechtsstaat in Polen en Hongarije, en welke rechtvaardiging gegeven kan worden voor de verschillende maatregelen van de 'weerbare democratie'. In het derde deel, ten slotte, gaan David Suurland, Dirk Verhofstadt en Paul Cliteur in op de specifieke uitdaging die de radicale islam met zich brengt voor democratische rechtsstaten.

De verschillende hoofdstukken in deze delen zijn kwalitatief weliswaar niet allemaal van hetzelfde niveau en vertonen niet allemaal dezelfde diepgang - iets dat overigens moeilijk te bereiken valt bij relatief uitgebreide bundels zoals deze maar dat neemt niet weg dat de bundel als geheel een interessant, goed en op punten uitdagend overzicht geeft van de verschillende aspecten (politiek, juridisch en filosofisch) van het vraagstuk van de weerbaarheid van de democratische rechtsstaat. Zo is de bijdrage van Molier bijvoorbeeld bijzonder verhelderend en biedt het hoofdstuk van Rijpkema een perfect startpunt voor de bundel. (Dat zijn 
analyse van 'democratie als zelfcorrectie', hoe waardevol ook, als ijkpunt fungeert voor een aantal andere bijdragen in de bundel heeft daarentegen niet altijd een toegevoegde waarde.)

Op het vlak van de inhoudelijke structuur van de bundel kunnen echter wel vraagtekens geplaatst worden bij de gemaakte keuzes, specifiek met betrekking tot de driedeling en de afbakening van het kernprobleem. De strekking van deze vraagtekens kan verduidelijkt worden door wederom kort te kijken naar het rapport van de commissie-Remkes. Dat de voorliggende recensie met dit rapport is begonnen, is immers geen toeval. Vanzelfsprekend bouwt dit rapport voor het onderdeel van de weerbare democratische rechtsstaat voort op het werk van Rijpkema - in die zin bestaat er een duidelijke parallel met De strijd om de democratie - maar de democratische waarborgen die in het eindrapport besproken worden zijn veel breder dan wat in de bundel uitgewerkt wordt. Daarnaast wijst de commissieRemkes zoals gezegd ook expliciet op de sterke relatie tussen de vraagstukken van inhoudelijke representatie en weerbaarheid. Qua waarborgen denkt de staatscommissie aan een versterking van het evenredige kiesstelsel, een betere rolverdeling tussen de Eerste en de Tweede Kamer, en 'een sterke en democratisch georganiseerde civil society' (p. 219). Een sterke maatschappelijke democratie kan bijvoorbeeld pas gecreëerd en in stand gehouden worden indien burgers over voldoende democratische kennis en vaardigheden beschikken en een gezonde mate van 'democratische gezindheid'.

De vraagstukken van 'democratische gezindheid' en 'maatschappelijke democratie' komen in De strijd om de democratie weliswaar aan bod - Ellian benadrukt meerdere malen het cruciale belang van een société démocratique - maar worden nergens expliciet uitgewerkt. Hoe kan democratische gezindheid specifiek gestimuleerd worden? Hoe voorkomen we - behalve op basis van een sanctionerend beleid dat gericht is op het verbieden van ondemocratische partijen en salafistische organisaties - dat burgers en groepen niet meer bereid zijn om zich aan de spelregels van onze democratische rechtsstaat te houden? Zijn nieuwe vormen van burgerparticipatie zinvol? Is het invoeren van een bindend correctief referendum een goed idee? Al deze vragen zijn essentieel om in combinatie met het vraagstuk van weerbaarheid te stellen. Dat geldt ook voor het vraagstuk van sociale gelijkheid, polarisering en toegenomen identiteitspolitiek; en wellicht zelfs dat van de democratische legitimiteit van constitutionele toetsing. Op al deze vlakken wordt de democratische rechtsstaat uitgedaagd en dienen oplossingen bedacht te worden om ondemocratische ontwikkelingen het hoofd te bieden en de weerbaarheid van de democratische rechtsstaat te verbeteren.

Vanzelfsprekend zouden de redacteurs van de bundel kunnen stellen dat het begrip 'weerbaarheid' of 'zelfverdediging' niet te ver opgerekt dient te worden en dat het boek vooral wil inzoomen op wat Rijpkema de derde verdedigingslinie van de democratische rechtsstaat noemt - de 'democratische verdedigingslinie' (p. 42) - en niet op de rechtsstatelijke verdedigingslinie en het democratische debat. Het punt is echter dat de bundel niet enkel gaat over de vraag of en zo ja wanneer politieke partijen verboden kunnen worden. Meerdere vijanden van de 
democratische rechtsstaat worden genoemd en meerdere verdedigingslinies besproken. Een betere keuze zou wellicht geweest zijn om het derde deel van de bundel niet enkel te wijden aan het thema van salafisme en radicale islam maar ook open te stellen voor andere bedreigingen voor de maatschappelijke democratie en de gebrekkige inhoudelijke representatie van ons parlementair stelsel. Op die manier zou de bundel ook de theoretische reflecties kunnen bieden die in het eindrapport van de commissie-Remkes niet altijd te vinden zijn.

Discussie over de juiste inhoudelijke oriëntatie van een bundel zal er achteraf echter altijd zijn. Deze bedenking doet dan ook weinig af aan de conclusie dat het boek een interessante en belangrijke bijdrage levert aan het debat over democratische zelfverdediging. 